Vol. 1 No. 3 November 2021, e-ISSN : 2797-0140 | p-ISSN : 2797-0590

\title{
UPAYA MENINGKATKAN KEMAMPUAN LITERASI SAINS DAN PSIKOMOTORIK PESERTA DIDIK MELALUI SCIENTIFIC HYBRID LEARNING DENGAN APLIKASI VIRTUAL LAB
}

\author{
LEO CHANDRA \\ Pascasarjana PMIPA, Universitas Indraprasta PGRI, Jakarta \\ e-mail: leochandra83@gmail.com
}

\begin{abstract}
ABSTRAK
Penelitian Tindakan Kelas ini bermaksud untuk mengetahui mengetahui dampak penggunaan Aplikasi Virtual Lab terhadap kemampuan Literasi Sains Peserta didik kelas X MIPA pada Mata pelajaran Fisika di SMA Negeri 2 Gunungputri Kabupaten Bogor. Penelitian ini dilaksanakan dalam dua siklus menggunakan teknik observasi kemampuan literasi data dan Psikomotorik peserta didik. Observasi yang dilakukan dalam penelitian ini adalah pengamatan langsung terhadap kegiatan peserta didik dalam melaksanakan praktikum fisika dengan menggunakan aplikasi virtual lab, serta mengukur hasil belajarnya dengan menggunakan test formatif. Penelitian ini mengambil populasi seluruh peserta didik kelas X MIPA serta sampel adalah peserta didik kelas X MIPA 1 sebanyak 36 orang yang dilaksanakan pada semester ganjil tahun ajaran 2020/2021. Hasil dari penelitian tindakan kelas ini memberikan gambaran peningkatan kemampuan literasi sains peserta didik dari siklus 1 sebesar $35 \%$ menjadi $78 \%$ pada siklus 2, serta peningkatan kemampuan Psikomotorik peserta didik dari $30 \%$ pada siklus 1 menjadi 80 pada siklus 2. Penelitian ini pula berdampak pada tingkat prosentase ketuntasan pencapaian target kompetensi yang ditetapkan yang pada awalnya hanya $48 \%$ meningkat menjadi $88 \%$. Peningkatan pencapaian target kompetensi ini merupakan salah satu indikator peningkatan hasil belajar peserta didik secara umum pada mata pelajaran Fisika.
\end{abstract}

Kata Kunci : Literasi Sains, Psikomotorik, Scientific Hybrid Learning, Virtual Lab

\section{ABSTRACT}

This Classroom Action Research intends to find out the impact of using the Virtual Lab Application on the Science Literacy Skills of Class X Mathematics and Natural Sciences students in Physics Subjects at SMA Negeri 2 Gunungputri, Bogor Regency. This research was carried out in two cycles using observation techniques for data literacy and psychomotor abilities of students. Observations made in this study were direct observations of student activities in carrying out physics practicum using virtual lab applications, and measuring learning outcomes using formative tests. This study took a population of all students of class $\mathrm{X}$ MIPA and the sample was students of class X MIPA 1 as many as 36 people who were carried out in the odd semester of the 2020/2021 academic year. The results of this classroom action research provide an overview of increasing students' scientific literacy skills from cycle 1 by $35 \%$ to $78 \%$ in cycle 2 , as well as increasing students' psychomotor abilities from $30 \%$ in cycle 1 to 80 in cycle 2 . the percentage level of completion of the achievement of the specified competency targets which was initially only $48 \%$ increased to $88 \%$. Increasing the achievement of this competency target is one indicator of improving student learning outcomes in general in Physics subjects.

Keywords: Scientific Literacy, Psychomotor, Scientific Hybrid Learning, Virtual Lab

\section{PENDAHULUAN}

Pada masa kondisi pandemi saat sekarang ini, dunia pendidikan terutama tingkat Sekolah Menengah Atas (SMA) mengalami tantangan yang sangat besar. Pendidikan harus terus berjalan dengan kondisi pandemi yang mengharuskan masyarakat termasuk peserta didik mengurangi mobilitas dan menjaga jarak. Walaupun dalam kondisi pandemi, setiap satuan pendidikan tetap harus mempersiapkan para peserta didik untuk memiliki kemampuan yang sesuai dengan tuntutan kompetensi abad 21 yang tidak berkurang sedikit pun, hal ini di 
sebabkan oleh sifat dunia pendidikan yang mempersiapkan peserta didik untuk berkembang 3 sampai dengan 4 tahun kedepan (saat peserta didik menyelesaikan proses pendidikan pandemi sudah berakhir).

Salah satu kompetensi yang harus dikembankan oleh para peserta didik dalam menghadapi era abad 21 adalah kemampuan literasi data. Menurut PISA mendefinisikan pengertian literasi Sains adalah sebagai kemampuan menggunakan pengetahuan sains, mengidentifikasi permasalahan dan menarik kesimpulan berdasarkan bukti-bukti berupa data dan fakta dalam rangka mengerti serta membuat keputusan tentang alam dan perubahan yang terjadi pada alam sebagai akibat aktivitas manusia. Menurut Rustaman (2006), Definisi PISA tersebut dalam implementasinya di Kegiatan Belajar Mengajar di satuan pendidikan adalah berupa Kegiatan Praktikum (dalam pembelajaran IPA). Kegiatan praktikum pada umumnya harus menghadirkan peserta didik dalam jumlah beberapa orang dalam satu keelompok (Jika praktikum Kelompok) dalam satu ruang lab dalam satu waktu. Hal tersebut dalam masa pandemi sangatlah tidak dianjurkan. Oleh karen itu para pendidik harus berinovasi untuk mencari strategi pembelajaran yang mampu beradaptasi dengan kondisi pandemi.

Salah satu strategi yang dikembangkan peneliti adalah menggunakan aplikasi virtual $l a b$ untuk melaksanakan praktikum fisika, dengan tidak menghadirkan peserta didik di lab secara fisik. Para peserta didik dapat melaksanakan praktikum dirumah masing-masing dengan menggunakan aplikasi tersebut dan menyelesaikan tugas-tugas dari guru melalui aplikasi tersebut. Selain itu, aplikasi ini juga dalam membantu para peserta didik mengembangkan kemampuan Psikomotoriknya, dimana kemampuan Psikomotorik ini dapat dilatih dengan cara praktikum dan indikatornya berupa keaktifan peserta didik dalam melaksanakan praktikum Menurut Suharso (2016), unsur terpenting dalam keberhasilan proses pembelajaran terdapat pada keaktifan peserta didik. Keaktifan belajar para peserta didik dapat menunjang tingkat keberhasilan para peserta didik menyelesaikan kompetensi yang diharapkan para pendidik. Kektifan ini secara langsung berkorelasi dengan hasil belajar peserta didik.

Hasil belajar adalah tingkat pencapaian dari seorang peserta didik dalam memahami subjek belajar yan dinyatakan dalam angka. Hasil belajar ini dapat menjadi dasar pengelompokkan siswa kedalah tiga kelompok yaitu kelompok Low, Kelompok Middle dan kelompok High atau dapat pula menjadi dasar seorang pendidik untuk melakukan remedial atau pengayaan. Menurut Sudjana (2017), pada hakekatnya hasil belajar merupakan perubahan tingkah laku peserta didik. Tingkah laku hasil pembelajaran mencakup definisi yang luas meliputi kognitif, Afektif dan Psikomotorik. Hal tersebut dapat mendeskripsikan bahwa terdapat keterkaitan antara Proses peningkatan kemampuan Literasi Sains peserta didik menggunakan aplikasi virtual lab dengan kemampuan psikomotorik sebagai hasil belajar.

Dalam hal ini peneliti memfokuskan pada perubahan paradigma yang masih banyak berkembang di kalangan pendidik terutama mata pelajaran fisika yang mengutamakan hasil belajar pada ranah kognitif dalam bentuk test yang menghasilkan angka-angka pencapaian nilai siswa. Para pendidik masih belum banyak yang menyentuh aspek kemampuan psikomotorik siswa secara lebih intens. Hal tersebut salah satunya adalah keterbatasan sarana penunjang berupa alat lab real. Oleh karena itu menurut pandangan peneliti, aplikasi virtual lab yang hanya sedikit membutuhkan pendanaan dapat dijadikan solusi mengatasi keterbatasan sarana penunjang lan karena biaya yang sangat tinggi. Sehingga dapat menyentuh seluruh lapisan satuan pendidikan.

Berdasarkan penjelasan tersebut, peneliti ingin melakukan pengukuran signifikansi dampak dari penggunaan aplikasi terhadap kemampuan Literasi Sains dan psikomotorik peserta didik, sehingga aplikasi yang digunakan dapat dijadikan alternatif solusi menghadapi kondisi pandemi.

\section{METODE PENELITIAN}

Penelitian tindakan kelas merupakan pengembangan dari salah satu jenis penelitian yaitu penelitian tindakan. Penelitian tindakan secara umum adalah jenis penelitian yang 


\section{Vol. 1 No. 3 November 2021, e-ISSN : 2797-0140 | p-ISSN : 2797-0590}

mengukur sejauh mana pengaruh sebuah treatment yang dilakukan oleh peneliti terhadap hasil yang diharapkan peneliti pada subjek penelitian. Menurut pendapat salah seorang ahli yaitu Kemmis (1988) dinyatakan oleh Wina Sanjaya penelitian tindakan adalah suatu bentuk penelitian reflektif dan kolektif yang dilakukan oleh peneliti dalam situasi sosial dalam meningkatkan penelaran praktik sosial mereka.

Dari penjelasan tersebut peneliti menyimpulkan bahwa penelitian tindakan kelas (PTK) adalah sebuah penelitian tindakan yang perlu intervensi dari peneliti berupa sebuah treatment yang akan diukur tingkat pengaruhnya terhadap subjek penelitian dan tujuan penelitian. Pada penelitian ini peneliti akan melakukan sebuah treatment berupa penggunaan aplikasi yang akan diukur pengaruhnya terhapat peningkatan kemampuan belajar peserta didik dari segi kemampuan Literasi data, kemampuan Psikomotorik dan hasil belajar.

Adapaun sampel dari penelitian ini adalah peserta didik SMA Negeri 2 Gunungputri kelas X MIPA 1 sebanyak 36 peserta didik dengan rincian 22 orang peserta didik perempuan dan 14 orang peserta didik laki-laki. Penelitian ini dilaksanakan dengan melalui beberapa tahapan yang mengacu pada model penelitian Tindakan Kurt Lewin. Konsep pokok penelitian tindakan Model Kurt Lewin terdiri dari empat komponen, yaitu perencanaan (planning), tindakan (acting), pengamatan (observing), refleksi (reflekting). Hubungan ke empat komponen tersebut dipandang sebagai siklus yang dapat digambarkan pada diagram berikut ;

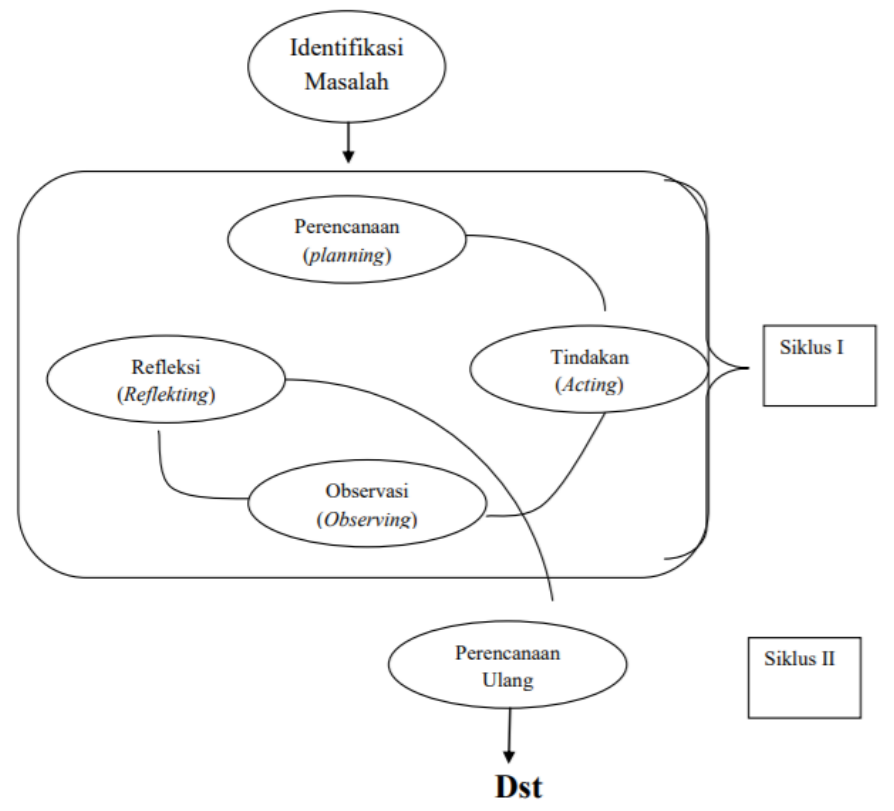

Gambar 1. Alur Pelaksanaan Penelitian

Penjelasan alur diatas

1. Menyusun perencanaan (planning). Pada tahap ini, kegiatan yang dilakukan peneliti adalah melakukan perencanaan mulai dari pengenalan aplikasi Virtual lab kepada peserta didik, proses instalasi aplikasi, persiapan RPP dan persiapan Lembar Kerja Siswa (LKS) yang menjadi guide bagi peserta didik dalam melaksanakan praktikum menggunakan aplikasi, mempersiapkan instrument untuk merekam dan menganalisis data mengenai proses dan hasil tindakan.

2. Melaksanakan tindakan (acting), pada tahap ini peneliti melaksanakan tindakan yang telah dirumuskan pada RPP dalam situasi daring dikarenakan kondisi pandemi, yang meliputi kegiatan awal, kegiatan inti dan kegiatan penutup

3. Melaksanakan pengamatan (observing). Pada tahap ini, peneliti mengamati proses kegiatan peserta didik dan mendokumentasikannya dengan instrument yang sudah di buat.

4. Melakukan refleksi (reflecting). Pada tahap ini yang harus dilakukan adalah mencatat hasil observasi, mengevaluasi hasil observasi, menganalisis hasil pembelajaran, 
mencatat kelemahan-kelemahan untuk dijadikan bahan penyusunan rancangan siklus berikutnya.

Setelah peneliti mendapatkan sejumlah data dari dokumentasi data yang tercantum dalam instrumen, maka data tersebut di analisis oleh peneliti. Secara umum peneliti menganalisa data tersebut dengan menggunakan tenik analisa deskriptif dengan tahapan pengumpulan data, penyajian data dan penarikan kesimpulan.

Data kuantitatif yang diperoleh berupa data nilai hasil belajar, yang merepresentasikan tingkat pencapaian kompetensi yang diharapkan. Selanjutnya berdasarkan Nilai data tersebut dibagi menjadi tiga kelompok yaitu kelompok A Belum tuntas apabila nilai di bawah KKM, Kelompok B tuntas apabila nilai sama dengan KKM dan Kelompok C melampaui apabila nilai lebih besar dari KKM. Lalu masing-masing kelompok di hitung jumlah peserta didik yang menjadi bagian dari masing-masing kelompok tersebut. Data jumlah peserta didik tiap kelompok di peroleh dari tiap siklus inilah yang dijadikan dasar pengambilan kesimpulan peneliti mengenai pengaruh treatment terhadap hasil penelitian.

\section{HASIL DAN PEMBAHASAN}

\section{Hasil}

Terdapat beberapa data yang terdokumentasikan mengenai hasil yang didapatkan dari pengamatan penggunaan aplikasi virtual lab ini. Data tersebut berupa data kualitatif berupa data survei peserta didik terhadap penggunaan aplikasi ini terhadap pemahaman konsep yang mereka pahami, dalam data ini peneliti menggali informasi kepada para siswa mengenai aplikasi virtual lab. Peneliti menggali informasi darai siswa apakah virtual lab dapat membantu siswa memahami konsep fisika secara praktis bukan hanya teoritis. Sehingga kemampuan praktis ini dapat mendukung kemampuan teoritisnya. Sedangkan data kuantitatifnya berupa hasil belajar yang disajikan dalam tabel berikut:

Tabel 1. Tingkat pemahaman siswa terhadap aplikasi

\begin{tabular}{|c|c|c|c|c|c|c|}
\hline No & $\begin{array}{l}\text { Jumlah } \\
\text { Siswa }\end{array}$ & $\begin{array}{c}\text { Sangat } \\
\text { paham }\end{array}$ & Paham & $\begin{array}{c}\text { Cukup } \\
\text { Paham }\end{array}$ & $\begin{array}{c}\text { Belum } \\
\text { Paham }\end{array}$ & Keterangan \\
\hline 1 & 36 & 0 & 2 & 30 & 4 & Siklus 1 \\
\hline 2 & 36 & 4 & 12 & 16 & 4 & Siklus 2 \\
\hline 3 & 36 & 10 & 16 & 8 & 2 & Siklus 3 \\
\hline
\end{tabular}

Selanjutnya saya sajikan data hasil belajar siswa kelas X MIPA 1 Semester satu tahun 2019/2020 sebanyak tiga siklus penelitian dibandingkan dengan kriteria ketuntasan minimal SMAN 2 gunungputri mata pelajaran Fisika.

Tabel 2. Hasil Belajar siswa

\begin{tabular}{|c|c|c|c|c|c|}
\hline No & Jumlah Siswa & Nilai $>$ KKM & Nilai = KKM & Nilai $<$ KKM & Keterangan \\
\hline 1 & 36 & 8 & 2 & 26 & Siklus 1 \\
\hline 2 & 36 & 14 & 2 & 20 & Siklus 2 \\
\hline 3 & 36 & 22 & 4 & 10 & Siklus 3 \\
\hline
\end{tabular}

Sedangkan data dari hasil belajar siswa selama tiga siklus diperoleh rerata nilai hasil belajar siswa adalah sebagai berikut

Tabel 3. Rerata Hasil Belajar Siswa

\begin{tabular}{|c|c|c|c|c|}
\hline No & KKM & Rerata Siklus 1 & Rerata Siklus 2 & Rerata Siklus 3 \\
\hline 1 & 68 & 63,86 & 68,91 & 78,36 \\
\hline
\end{tabular}




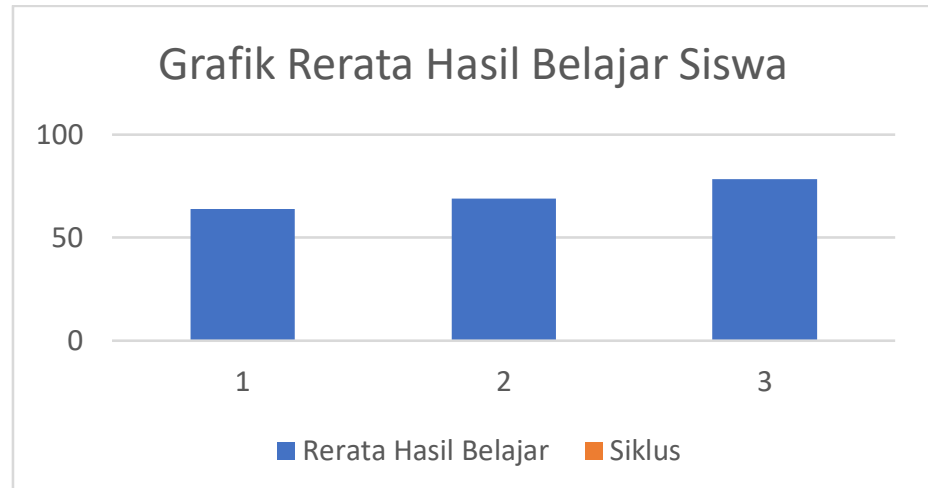

Gambar 2. Diagram peningkatan hasil belajar siswa

Berdasarkan data diatas, menunjukkan bahwa terdapat peningkatan jumlah siswa yang mencapai nilai KKM dan diatas KKM serta terdapat peningkatan rata-rata nilai hasil belajar selama tiga siklus.

\section{Pembahasan}

Berdasarkan data hasil belajar yang mengalami peningkatan baik dalam segi kuantitas jumlah siswa yang mencapai KKM ataupun rata-rata nilai hasil belajarnya. Hal ini menunjukkan bahwa aplikasi Virtual Lab dapat dengan mudah dipahami siswa serta mampu memberikan gambaran real kejadian fisika dalam proses kegiatan belajar mengajar secara daring dan luring. Sehingga mampu meningkatkan daya serap siswa akan materi yang di sampaikan. Data ini juga menunjukkan bahwa Virtual lab dapat dijadikan alternatif solusi untuk proses pembelajaran secara daring, terlebih saat pandemi seperti sekarang ini. Pada penelitian yang telah dilakukan oleh Kusdiastuti (2017) yang menyatakan bahwa model pembelajaran inkuri berbantuan laboratorium virtual berpengaruh terhadap penguasaan konsep fisika peserta didik MA DI Putri Nurul Hakim Kediri Tahun Pelajaran 2015/2016. Hal ini menunjukkan bahwa lab virtual dalam bentuk aplikasi apapun dapat meningkatkan hasil belajar siswa. Penelitian lain yang sejalan dengan penelitian ini telah dilakukan oleh Yusuf (2020), yang menyatakan bahwa penggunaan e-learning berbasis virtual laboratory dapat meningkatkan kualitas pembelajaran dan kemampuan metakognitif siswa dalam praktikum fisika.

\section{KESIMPULAN}

Berdasarkan data dan pembahasan dapat di simpulkan bahwa penggunaan aplikasi virtual lab dapat meningkatkan kemampuan literasi sains dan psikomotorik siswa dengan pencapaian hasil belajar sebagai indikatornya. Terdapat peningkatan sebesar 44,5\% antara jumlah siswa yang melampaui KKM pada siklus 1 sebesar $27,7 \%$ dibandingkan pada siklus 3 sebesar $72,2 \%$.

\section{DAFTAR PUSTAKA}

Arikunto, S., Suhardjono., \& Supardi. (2011). Penelitian Tindakan Kelas, Jakarta: PT Bumi Aksara.

Azhar Arsyad. (2013). Media Pembelajaran. PT Raja Grafindo Persada. Jakarta Harjanto. (2006). Perencanaan Pengajaran. PT. Rineka Cipta. Jakarta

Husamah. (2014). Pembelajaran Bauran, Blended Learning. Prestasi Pustaka Publisher. Jakarta

Irfan Yusuf, Sri Wahyu Widyaningsih. (2020). Implementing E-Learning-Based Virtual Laboratory Media to Students' Metacognitive Skills. Paper iJET Vol. 15, No. 5

Kusdiastuti, Mahesti., Harjono, Ahmad., Sahidu, Hairunnisyah., \& Gunawan. (2016). Pengaruh Model Pembelajaran Inkuiri Berbantuan Laboratorium Virtual Terhadap Penguasaan Konsep Fisika Peserta Didik Jurnal Pendidikan Fisika dan Teknologi. Volume II No 3 